\title{
Solar photo-Fenton process on the abatement of antibiotics at a pilot scale: Degradation kinetics, ecotoxicity and phytotoxicity assessment and removal of antibiotic resistant enterococci
}

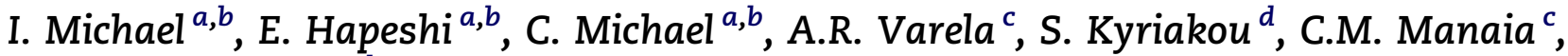 \\ D. Fatta-Kassinos ${ }^{a, b, *}$ \\ ${ }^{a}$ Department of Civil and Environmental Engineering, University of Cyprus, 75 Kallipoleos St., 1678 Nicosia, Cyprus \\ ${ }^{\mathrm{b}}$ Nireas, International Water Research Centre, University of Cyprus, Cyprus \\ ${ }^{c}$ CBQF/Escola Superior de Biotecnologia, Universidade Católica Portuguesa, R. Dr. António Bernardino de Almeida, 4200-072 Porto, Portugal \\ ${ }^{\mathrm{d}}$ S.K. Euromarket Ltd., Water and Wastewater Engineering, 3308 Lemessos, Cyprus
}

\section{A R T I C L E I N F O}

\section{Article history:}

Received 27 April 2012

Received in revised form

25 July 2012

Accepted 26 July 2012

Available online 7 August 2012

Keywords:

Antibiotics

Antibiotic resistance

Enterococci

Phytotoxicity

Solar photo-Fenton

Wastewater reuse

\begin{abstract}
A B S T R A C T
This work investigated the application of a solar driven advanced oxidation process (solar photo-Fenton), for the degradation of antibiotics at low concentration level $\left(\mu \mathrm{g} \mathrm{L}^{-1}\right.$ ) in secondary treated domestic effluents at a pilot-scale. The examined antibiotics were ofloxacin (OFX) and trimethoprim (TMP). A compound parabolic collector (CPC) pilot plant was used for the photocatalytic experiments. The process was mainly evaluated by a fast and reliable analytical method based on a UPLC-MS/MS system. Solar photo-Fenton process using low iron and hydrogen peroxide doses $\left(\left[\mathrm{Fe}^{2+}\right]_{0}=5 \mathrm{mg} \mathrm{L} \mathrm{L}^{-1}\right.$; $\left[\mathrm{H}_{2} \mathrm{O}_{2}\right]_{0}=75 \mathrm{mg} \mathrm{L}^{-1}$ ) was proved to be an efficient method for the elimination of these compounds with relatively high degradation rates. The photocatalytic degradation of OFX and TMP with the solar photo-Fenton process followed apparent first-order kinetics. A modification of the first-order kinetic expression was proposed and has been successfully used to explain the degradation kinetics of the compounds during the solar photoFenton treatment. The results demonstrated the capacity of the applied advanced process to reduce the initial wastewater toxicity against the examined plant species (Sorghum saccharatum, Lepidium sativum, Sinapis alba) and the water flea Daphnia magna. The phytotoxicity of the treated samples, expressed as root growth inhibition, was higher compared to that observed on the inhibition of seed germination. Enterococci, including those resistant to OFX and TMP, were completely eliminated at the end of the treatment. The total cost of the full scale unit for the treatment of $150 \mathrm{~m}^{3}$ day $^{-1}$ of secondary wastewater effluent was found to be $0.85 € \mathrm{~m}^{-3}$.
\end{abstract}

(c) 2012 Elsevier Ltd. All rights reserved.

\footnotetext{
* Corresponding author. Department of Civil and Environmental Engineering, University of Cyprus, 75 Kallipoleos St., 1678 Nicosia, Cyprus. Tel.: +357 22892275; fax: +357 22892295.

E-mail address: dfatta@ucy.ac.cy (D. Fatta-Kassinos).

0043-1354/\$ - see front matter @ 2012 Elsevier Ltd. All rights reserved.

http://dx.doi.org/10.1016/j.watres.2012.07.049
} 


\section{Introduction}

Antibiotics are among the most frequently prescribed medications since they are commonly used in human and veterinary medicine for the purpose of treating bacterial infections (Kümmerer, 2009). Antibiotics may escape conventional biological treatment and thus enter receiving environmental media either in their parent form or as transformation products. It appears from the literature that the greatest risk related to their presence in the environment is their potential to cause antibiotic resistance among bacteria (Akiyama and Savin, 2010; Novo and Manaia, 2010). Although antibiotics are found in the environment at subinhibitory levels, relatively low concentrations of antimicrobial agents can still promote bacterial resistance (Castiglioni et al., 2008).

Reusable treated wastewater (especially for irrigation purposes in countries with dry weather conditions) should be free of antibiotic compounds; therefore the application of new and improved wastewater treatment technologies are a necessary task. Advanced Oxidation Processes (AOPs) are considered promising methods for the remediation of contaminated wastewaters containing non-biodegradable organic pollutants (Oller et al., 2011; Rizzo, 2011). These processes involve the generation of powerful transitory species, principally the hydroxyl radical (HO) (Andreozzi et al., 1999). Among the various AOPs, Fenton process has been extensively used with success for the oxidation of many classes of organic compounds due to its high efficiency to generate $\mathrm{HO}^{*}$ by the catalytic decomposition of hydrogen peroxide in reaction with ferrous (or ferric) ions in acidic medium (Perez-Estrada et al., 2005). In the photoFenton process, additional reactions occur in the presence of light (artificial or solar) that produce additional HO' (Pignatello, 1992), thus increasing the efficiency of the process.

OFX is a second generation fluoroquinolone antibiotic (Okeri and Arhewoh, 2008). It is an orally administered broad spectrum antibacterial drug active against most Gramnegative bacteria, many Gram-positive bacteria (staphylococci and enterococci) and some anaerobes (Nau et al., 1994). TMP belongs to a family of synthetic 2,4-diaminopyrimidines and is used either alone or in combination with sulfonamides for the treatment of specific bacterial infections ( $\mathrm{Li}$ et al., 2005). It is a broad-spectrum antimicrobial agent which inhibits the enzyme dihydrofolate reductase (Barbarin et al., 2002). OFX and TMP have been reported in many environmental monitoring studies, detected in wastewater treatment plant effluents and in natural waters worldwide at concentrations of $\mu \mathrm{g} \mathrm{L}^{-1}$ (Watkinson et al., 2009; Li and Zhang, 2011).

The overall aim of this work was to (i) investigate at a pilotscale the degradation of OFX and TMP when present in secondary effluents at $\mu \mathrm{g} \mathrm{L}^{-1}$ concentration level; (ii) determine the degradation kinetics for both compounds; (iii) assess the acute toxicity of the parent compounds and their oxidation by-products generated during the process using a set of bio- and phyto- assays and (iv) assess the efficiency of the process to remove the antibiotic resistant enterococci.

\section{Materials and methods}

\subsection{Chemicals}

The standards of antibiotics (OFX, Sigma Aldrich; TMP, Fluka) used were of high purity grade and were not subjected to any further purification. The reagents used in the solar photoFenton experiments were $\mathrm{FeSO}_{4} \cdot 7 \mathrm{H}_{2} \mathrm{O}$ (Sigma Aldrich) and $\mathrm{H}_{2} \mathrm{O}_{2}$ (30\% w/w, Merck). The $\mathrm{pH}$ of the wastewater was adjusted by $2 \mathrm{~N} \mathrm{H}_{2} \mathrm{SO}_{4}$ (Merck). The Fenton reaction was terminated at specific time intervals by adding: (i) methanol (Fluka) for the chromatographic analysis, (ii) anhydrous $\mathrm{Na}_{2} \mathrm{SO}_{3}$ (Sigma Aldrich) for the DOC measurements and (iii) $\mathrm{MnO}_{2}$ (particle size $10 \mu \mathrm{m}$, reagent grade $\geq 90 \%$ ) (Sigma Aldrich) for the COD determination. LC/MS-grade solvents such as methanol (Fluka) and acetonitrile (Sigma Aldrich), formic acid (Fluka) and ammonium acetate (Sigma Aldrich) were used for the chromatographic analysis. Ultrapure water (Milli-Q) was also used. For toxicity and microbiological analyses the treated solutions were neutralized with $2 \mathrm{~N} \mathrm{NaOH}$ (Merck) while the residual $\mathrm{H}_{2} \mathrm{O}_{2}$ was removed from the treated samples with commercially available catalase solution (Micrococcus lysodeikticus 170,000 $\mathrm{U} \mathrm{mL}^{-1}$, Fluka) (Zapata et al., 2009a).

\subsection{Experimental procedure}

The experiments were performed using a compound parabolic collector (CPC) pilot plant installed at the sewage treatment plant at the University of Cyprus (UCY), for solar photocatalytic degradation applications. The pilot plant is comprised of twelve borosilicate glass tubes $(\varnothing 55 \mathrm{~mm})$ and is mounted on curved polished aluminum reflectors. The reflectors are mounted on a fixed platform tilted at the local latitude $\left(35^{\circ}\right)$. Storage tank, flow meters, sensors $(\mathrm{pH}, \mathrm{DO}$ and $\mathrm{T}$ ), air blower, UV radiometer (UV_air_ABC), control panel, pipes, and fittings complete the installation. The storage tank of the pilot unit is directly connected to the main secondary tank of the sewage treatment plant at the UCY and was filled with $250 \mathrm{~L}$ of wastewater for each experiment. The plant was operated in batch mode. The wastewater flows directly from one tube to the other and finally to the reservoir tank. A centrifugal pump $\left(600 \mathrm{~L} \mathrm{~h}^{-1}\right)$ returns the wastewater from the tank to the collectors in a closed circuit. The overall volume capacity of the reactor $V_{T}$ is $250 \mathrm{~L}$ and the total irradiated volume $V_{i}$ (tubes volume) is $85.4 \mathrm{~L}$. The irradiated surface of the pilot plant is $5.65 \mathrm{~m}^{2}$. The secondary effluent was analyzed before use for a number of quality characteristics (Table 1). Note that OFX and TMP were not detected in the secondary effluent by UPLC-MS/MS.

The secondary effluent before entering the tank passes through a cylindrical filter $(200 \mu \mathrm{m}$ pore size, $\varnothing 25.4 \mathrm{~mm}$, PALAPLAST, Greece) installed at the entrance of the storage tank. This is necessary to avoid fouling problems in the mechanical parts of the pilot plant. The temperature in the reactor as well as the UV solar radiation was continuously recorded. The UV radiometer is mounted on the platform of the CPCs. During the loading of the reactor with the 
Table 1 - Main qualitative characteristics of the secondary treated effluent used for the solar Fenton process.

\begin{tabular}{lc} 
Parameter & Value range $^{\mathrm{a}}$ \\
\hline $\mathrm{pH}\left(20^{\circ} \mathrm{C}\right)$ & $6.50-7.21$ \\
Conductivity $\left(\mu \mathrm{S} \mathrm{cm}^{-1}\right)\left(20^{\circ} \mathrm{C}\right)$ & $1593-1677$ \\
$\mathrm{TSS}\left(\mathrm{mg} \mathrm{L}^{-1}\right)$ & $55.14-48.33$ \\
$\mathrm{NO}_{3}^{-}\left(\mathrm{mg} \mathrm{L}^{-1}\right)$ & $33.23-36.07$ \\
$\mathrm{Total} \mathrm{N}\left(\mathrm{mg} \mathrm{L}^{-1}\right)$ & $35.25-38.00$ \\
$\mathrm{PO}_{4}^{3-}\left(\mathrm{mg} \mathrm{L}^{-1}\right)$ & $2.65-3.11$ \\
$\mathrm{Total} \mathrm{P}\left(\mathrm{mg} \mathrm{L}^{-1}\right)$ & $3.53-3.89$ \\
$\mathrm{COD}\left(\mathrm{mg} \mathrm{L}^{-1}\right)$ & $25.00-27.00$ \\
$\mathrm{DOC}\left(\mathrm{mg} \mathrm{L}^{-1}\right)$ & $6.29-8.60$ \\
$\mathrm{BOD}\left(\mathrm{mg} \mathrm{L}^{-1}\right)$ & $11.00-12.00$ \\
$\mathrm{Fe}\left(\mathrm{mg} \mathrm{L}^{-1}\right)$ & $0.283-0.302$ \\
$\mathrm{Cu}\left(\mathrm{mg} \mathrm{L}^{-1}\right)$ & $0.195-0.209$ \\
$\mathrm{Cd}\left(\mathrm{mg} \mathrm{L}^{-1}\right)$ & $0.11-0.14$ \\
$\mathrm{Na}\left(\mathrm{mg} \mathrm{L}^{-1}\right)$ & $11.88-13.24$ \\
$\mathrm{~K}\left(\mathrm{mg} \mathrm{L}^{-1}\right)$ & $24.56-26.84$ \\
\hline a Mean value of three separate measurements. & \\
\hline
\end{tabular}

chemicals, the collectors were covered with a thick UV resistant canvas to avoid any photoreaction. At the beginning, the reactor was filled with the secondary treated wastewater. Then a predetermined volume of standard solution of OFX or TMP was added and after homogenization (15 min) a sample was taken, representing the initial drug concentration. The recirculation of the solution in the reactor was chosen to be $15 \mathrm{~min}$, time duration sufficient for good mixing, according to the operative flow rate and the detection of the examined compound at the outlet of the system. The $\mathrm{pH}$ was then adjusted $(\mathrm{pH}=2.8-2.9)$ with $2 \mathrm{~N} \mathrm{H}_{2} \mathrm{SO}_{4}$ and the appropriate volume of ferrous solution was added. Mixing was followed for $15 \mathrm{~min}$. Then, the predetermined amount of hydrogen peroxide was added. A sample was taken after some minutes of dark Fenton process (zero-illumination time) and the collectors were uncovered. At this time solar photo-Fenton process began. During the process, samples were withdrawn at specified intervals and were analyzed. In addition, experiments were performed at the inherent $\mathrm{pH}$ value $(\mathrm{pH}=7-8)$ of the wastewater.

The comparison of the data deriving from different days at different times of the day and under different solar illumination conditions, was performed after applying Eq. (1) to "normalized illumination time" (Gernjak et al., 2006; Klamerth et al., 2010). In this equation $t_{n}$ is the experimental time for each sample, UV is the average solar ultraviolet radiation $(\lambda<400 \mathrm{~nm})$ measured between $t_{n-1}$ and $t_{n}$, and $t_{30 \mathrm{~W}, n}$ is the "normalized illumination time". In this case, time refers to a constant solar UV power of $30 \mathrm{~W} \mathrm{~m}^{-2}$ (typical solar UV power on a perfectly sunny day around noon).

$\mathrm{t}_{30 \mathrm{~W}, n}=\mathrm{t}_{30 \mathrm{~W}, n-1}+\Delta \mathrm{t}_{n} \frac{\mathrm{UV}}{30} \frac{\mathrm{V}_{\mathrm{i}}}{\mathrm{V}_{\mathrm{T}}} ; \quad \Delta \mathrm{t}_{n}=\mathrm{t}_{n}-\mathrm{t}_{n-1}$

where $V_{T}$ and $V_{i}$ is the total and irradiated volume, respectively.

Furthermore, considering the fact that the reaction rate during the solar photo-Fenton process depends strongly on temperature (Zapata et al., 2009b), Eq. (1) can be transformed (using the Arrhenius equation) to Eqs. (2a, b) using the apparent rate constants of each compound at $25{ }^{\circ} \mathrm{C}$ which have been determined from the bench scale experiments.

$\mathrm{t}_{30 \mathrm{WT}, n}=\mathrm{t}_{30 \mathrm{WT}, n-1}+\Delta \mathrm{t}_{n} \frac{\overline{\mathrm{UV}}}{30} \frac{\mathrm{V}_{\mathrm{i}}}{\mathrm{V}_{\mathrm{T}}}\left[1+0.035\left(\bar{\theta}-25_{\mathrm{C}}^{\circ}\right)\right] \cdot \mathrm{OFX}$

$\mathrm{t}_{30 \mathrm{wT}, n}=\mathrm{t}_{30 \mathrm{wT}, n-1}+\Delta \mathrm{t}_{n} \frac{\overline{\mathrm{UV}}}{30} \frac{\mathrm{V}_{\mathrm{i}}}{\mathrm{V}_{\mathrm{T}}}\left[1+0.054\left(\bar{\theta}-25_{\mathrm{C}}^{\circ}\right)\right] \cdot \mathrm{TMP}$

where $t_{30 \mathrm{WT}, n}$ is the normalized time for each sample at $25^{\circ} \mathrm{C}$, $\overline{\mathrm{UV}}$ is the average solar ultraviolet radiation measured between $t_{n}-1$ and $t_{n}$, and $\bar{\theta}$ is the average temperature between $t_{n-1}$ and $t_{n}$. The value of $30 \mathrm{~W} \mathrm{~m}^{-2}$ was used as the average value for the ultraviolet solar irradiation according to the UV data provided directly by the UV radiometer which is installed on the plant. The collected UV data were confirmed with the data provided by the Cyprus Meteorological Service. It is important to mention that the normalized illumination time, calculated using the Eqs. $(2 a, b)$, is lower than the actual experimental time $\left(t_{\exp }\right)$. This is because the Eqs. $(2 a, b)$ include the term $V_{\mathrm{i}} / \mathrm{V}_{\mathrm{T}}$ and the irradiated volume is significantly lower than the total volume of the treated wastewater $\left(\mathrm{V}_{\mathrm{i}} \approx \mathrm{V}_{\mathrm{T}} / 3\right)$.

\subsection{Toxicity}

Toxicity measurements were carried out, in samples taken at various times during the photocatalytic treatment, with: (a) the Phytotestkit microbiotest (MicroBioTests Inc.) and (b) the Daphtoxkit $\mathrm{F}^{\mathrm{TM}}$ magna toxicity test. Toxicity tests were conducted according to the standard operating protocols for three plant species and for Daphnia magna (ISO 6341:1996), respectively. The residual hydrogen peroxide was removed from the treated samples with catalase prior to analysis.

The Phytotestkit microbiotest measures the decrease (or the absence) of germination and early growth of plants which are exposed directly to the samples spiked onto a thick filter paper. The filter is provided by the kit manufacturer (MicroBioTests Inc.). A control test was performed using tap water. The plants used for the Phytotestkit microbiotest were: the monocotyl Sorgho (Sorghum saccharatum), the dicotyl garden cress (Lepidium sativum) and the dicotyl mustard (Sinapis alba). These species are frequently used in phytotoxicity analyses due to their rapid germination and growth of roots and shoots and their sensitivity to low concentrations of phytotoxic substances (MicroBioTests Inc.).

The test results were evaluated comparing the mean number of germinated seeds and the mean root and shoot length for the three replicates in the control and in each examined sample. The percentage effect of the chemical compounds on seed germination (GI), root growth inhibition (RI) and shoot growth inhibition (SI) was calculated applying the following formula.

GI or $\mathrm{RI}$ or $\mathrm{SI}(\%)=\frac{A-B}{A} \times 100$

where $A$ is the average number of germinated seeds or average root length or average shoot length, respectively in the control and $B$ is the respective value for the test solution. The experiments were performed in triplicate. 
Daphtoxkit $F^{\mathrm{TM}}$ toxicity test is based on the observation of the D. magna immobilization after 24 and $48 \mathrm{~h}$ of exposure to the treated samples.

\subsection{Enumeration of total cultivable and antibiotic resistant enterococci}

In order to assess the removal of antibiotic resistant bacteria of enteric origin, commonly found in wastewaters and used as microbiological indicators of water quality, total and antibiotic resistant enterococci were monitored. Enterococci enumeration was based on the membrane filtration method as described elsewhere (Ferreira da Silva et al., 2006; Novo and Manaia, 2010). Briefly, bacteria were enumerated on $\mathrm{m}$ Enterococcus agar (Enterococcus Selective Agar, Fluka) or on this medium supplemented with $1 \mathrm{mg} \mathrm{L}^{-1}$ of TMP or OFX. Antibiotic stock solutions $\left(0.5 \mathrm{~g} \mathrm{~L}^{-1}\right)$ were prepared by dissolving a specified mass of each compound in deionized water, were sterilized by filtration and then spiking of the appropriate volume into the medium solution was carried out. The final antibiotic concentrations in the culture medium were determined according to the Minimal Inhibitory Concentrations (MIC) as reported by Andrews (2009).

Samples from the solar photo-Fenton experiments were mixed with catalase solution to remove the residual hydrogen peroxide and neutralized with $2 \mathrm{~N} \mathrm{NaOH}$. Serial dilutions were prepared in saline solution $(\mathrm{NaCl} 0.85 \%)$ and filtered through filtering membranes (mixed cellulose ester, $0.45 \mathrm{~mm}$ pore size, $47 \mathrm{~mm}$ diameter, Millipore). The membranes were placed onto the culture media and incubated for $48 \mathrm{~h}$ at $37^{\circ} \mathrm{C}$. After the incubation period, the number of colony forming units (CFU) was registered. CFU determinations were considered reliable if the filtering membranes contained between 10 and 100 colonies. The prevalence of antibiotic resistant enterococci was calculated as the ratio between the CFU mL $\mathrm{mL}^{-1}$ observed on antibiotic supplemented culture medium and the CFU $\mathrm{mL}^{-1}$ observed on the same medium without antibiotics (Novo and Manaia, 2010). All analyses were made in triplicate for each sample.

For each antibiotic, the antibiotic resistance (\%) was calculated by directly comparing the counts on the antibiotic plate with the corresponding counts on the plate without antibiotic (Eq. (4)).

\%Resistance $=\frac{\left(\frac{\mathrm{CFU}}{\mathrm{mL}}\right) \text { medium with antibiotic }}{\left(\frac{\mathrm{CFU}}{\mathrm{mL}}\right) \text { medium without antibiotic }} \times 100$

\subsection{Analytical methods}

All analyses were performed on an ACQUITY TQD UPLC-MS/ MS system (Waters) using a method specifically developed for this application (Michael et al., 2012). Data acquisition was performed with positive electrospray in multiple reaction monitoring mode (MRM), recording the transitions between the precursor ion and the most abundant fragment ions. The most abundant transition product ion was typically used for quantification of the target compound, while the second transition product, together with the ratio of the intensities of the two transitions, were used for confirmation purposes. Column BEH Shield RP18 (1.7 $\mu \mathrm{m}$; $2.1 \times 50$ mm; Waters $)$ was used for the chromatographic analysis with the mobile phase consisting of $0.1 \mathrm{mM}$ ammonium acetate in water $+0.01 \%$ formic acid (eluent A) and $0.1 \mathrm{mM}$ ammonium acetate in methanol $+0.01 \%$ formic acid (eluent B). Oasis HLB cartridges (200 mg, Waters Corporation) were used for the sample preconcentration.

Dissolved organic carbon (DOC) was monitored by direct injection of the filtered samples (0.22 $\mu \mathrm{m}$, Millipore) into a Shimadzu TOC analyzer. Chemical oxygen demand (COD) was measured with Merck ${ }^{\circledR}$ Spectroquant kits and the absorbance of the samples was measured at $445 \mathrm{~nm}$. Biodegradability was measured by the 5-day biochemical oxygen demand $\left(\mathrm{BOD}_{5}\right)$ test according to the standard methods protocol (Clesceri et al., 1998). The residual hydrogen peroxide remaining in the treated samples was measured using the spectrophotometric method employing ammonium metavanadate $\left(\lambda_{\max }=450 \mathrm{~nm}\right)$ as described by Nogueira et al. (2005). The presence of $\mathrm{H}_{2} \mathrm{O}_{2}$ in the treated samples was also monitored using Merckoquent ${ }^{\circledR}$ test sticks. Colorimetric determination of total iron concentration with 1,10-phenanthroline was performed following ISO 6332 method. The photometric measurements were performed using a double beam UV-vis Jasco V-530 spectrophotometer.

\section{Results and discussion}

Taking into consideration that the typical environmental concentrations of antibiotics in the effluents are in the ng$\mu \mathrm{g} \mathrm{L}^{-1}$ range, it was decided to work with an initial concentration of $100 \mu \mathrm{g} \mathrm{L}^{-1}$ of OFX and TMP, which is a compromise between (i) a sufficiently high concentration to characterize the degradation kinetics using available analytical techniques, and (ii) a low enough concentration to simulate real environmental conditions.

\subsection{Photolysis}

Preliminary photolysis experiments (solar irradiation alone) were carried out to determine its effect to the overall photocatalytic process. Photolysis was performed at initial concentration of $100 \mu \mathrm{g} \mathrm{L}^{-1}$ (for each compound) in acidic $\mathrm{pH}$ (2.8-2.9) and for a period of $240 \mathrm{~min}\left(t_{\mathrm{exp}}\right)$. The photolytic experiments did not exhibit significant degradation for any of the compounds. The degradation observed was $17.7 \%$ $\left(t_{30 \mathrm{WT}, n}=53.9 \mathrm{~min}\right)$ for OFX and $13.7 \%\left(\mathrm{t}_{30} \mathrm{wT,n}=37 \mathrm{~min}\right)$ for TMP (data not shown). The photolytic degradation was accompanied by a very low reduction in DOC (6-7\%).

\subsection{Solar photo-Fenton experiments}

One important issue of the pilot scale study was to find out if the solar photo-Fenton process is able to degrade completely the investigated compounds present at $\mu \mathrm{g} \mathrm{L}^{-1}$ concentration levels in a wastewater matrix containing dissolved organic matter (DOM) at much higher concentration level (6.29-8.60 $\mathrm{mg} \mathrm{L}^{-1}$ ) than the pharmaceutical level. For the solar photo-Fenton experiments a concentration of iron at $5 \mathrm{mg} \mathrm{L}^{-1}$ 
was chosen considering the fact that this concentration is: (a) capable to achieve relatively high degradation rates as showed by the bench scale experiments in a previous work (Michael et al., 2010) and (b) to avoid the requirement for iron removal at the end of the process according to the existing regulations concerning iron discharge limits (Cyprus Law: 106(I)/2002).

Preliminary solar photo-Fenton experiments were carried out using $5 \mathrm{mg} \mathrm{L}^{-1}$ of $\mathrm{Fe}^{2+}$ at several $\mathrm{H}_{2} \mathrm{O}_{2}$ doses (between 25 and $100 \mathrm{mg} \mathrm{L}^{-1}$ ) to establish the best peroxide dose for the antibiotics removal. It is important to point out that the concentration of iron in the secondary wastewater (0.298-0.302 $\mathrm{mg} \mathrm{L}^{-1}$, see Table 1 ) is low compared with the concentration of iron added $\left(5 \mathrm{mg} \mathrm{L}^{-1}\right)$ and therefore it does not change significantly the concentration of the total iron for the solar photo-Fenton process.

The complete removal of OFX and TMP substrate was accomplished with $75 \mathrm{mg} \mathrm{L}^{-1}$ of $\mathrm{H}_{2} \mathrm{O}_{2}$ within $180 \mathrm{~min}\left(\mathrm{t}_{\text {exp }}\right)$ of solar irradiation; at lower $\mathrm{H}_{2} \mathrm{O}_{2}$ doses $\left(25\right.$ and $50 \mathrm{mg} \mathrm{L}^{-1}$ ) more irradiation time $\left(t_{\text {exp }}=240 \mathrm{~min}\right.$ ) was needed for the complete degradation of the compounds whereas at $100 \mathrm{mg} \mathrm{L}^{-1}$ of $\mathrm{H}_{2} \mathrm{O}_{2}$ the substrate degradation and the organic content (DOC, COD) removal was similar to that at $75 \mathrm{mg} \mathrm{L}^{-1} \mathrm{H}_{2} \mathrm{O}_{2}$ (data not shown). The similar results obtained using $100 \mathrm{mg} \mathrm{L}^{-1}$ of $\mathrm{H}_{2} \mathrm{O}_{2}$ with that of $75 \mathrm{mg} \mathrm{L}^{-1} \mathrm{H}_{2} \mathrm{O}_{2}$ are probably attributed to the enhancement of the competition reactions, mainly the recombination of $\mathrm{HO}^{\circ}$ and the reaction of $\mathrm{HO}^{\circ}$ with $\mathrm{H}_{2} \mathrm{O}_{2}$, thus contributing to the $\mathrm{HO}^{\circ}$ scavenging (Tamimi et al., 2008).

Fig. 1(a) shows the evolution of the photocatalytic degradation of OFX and TMP during the solar photo-Fenton oxidation $\left(\left[\mathrm{Fe}^{2+}\right]=5 \mathrm{mg} \mathrm{L}^{-1},\left[\mathrm{H}_{2} \mathrm{O}_{2}\right]=75 \mathrm{mg} \mathrm{L}^{-1}\right)$ vs the normalized time, $t_{30} \mathrm{WT}, n_{n}$. In the same figure the respective curves of peroxide consumption are also presented. OFX was completely degraded after $t_{30} \mathrm{wT,n}=38.7 \mathrm{~min}$ of treatment $\left(\mathrm{H}_{2} \mathrm{O}_{2}\right.$ consumption $=33.8 \mathrm{mg} \mathrm{L}^{-1}$ ) whereas TMP was completely degraded at $t_{30} \mathrm{wT}, n=20.1 \mathrm{~min} \quad\left(\mathrm{H}_{2} \mathrm{O}_{2}\right.$ consumption $\left.=30.8 \mathrm{mg} \mathrm{L}^{-1}\right)$. It is important to note that degradation of the substrates started $15 \mathrm{~min}$ before uncovering the reactor $\left(t_{\exp }=-15 \mathrm{~min}\right.$, Fenton reaction) with $75.2 \%$ $\left([\mathrm{OFX}]_{\text {residual }}=20.8 \mu \mathrm{g} \mathrm{L}^{-1}\right)$ and $82.8 \%\left([\mathrm{TMP}]_{\text {residual }}=11.4 \mu \mathrm{g} \mathrm{L}^{-1}\right)$ degradation of OFX and TMP, respectively.

The experiments were repeated under the same conditions in the absence of solar light (collectors were covered). The dark Fenton experiments were performed in order to investigate the efficiency of the process and thus the possibility of the continuous operation of the plant overnight. As shown in Fig. 1(b), a significant degradation of the compounds under dark conditions was achieved. The maximum degradation of the compounds during the dark Fenton was $78.6 \%\left(\mathrm{H}_{2} \mathrm{O}_{2}\right.$ consumption $\left.=23.7 \mathrm{mg} \mathrm{L}^{-1}\right)$ for OFX and 92.7\% $\left(\mathrm{H}_{2} \mathrm{O}_{2}\right.$ consumption $=25.8 \mathrm{mg} \mathrm{L}^{-1}$ ) for TMP at $180 \mathrm{~min}$ of treatment for both compounds.

Although the degradation of both compounds was complete in 180 min under solar photo-Fenton process, DOC determinations showed no substantial mineralization. DOC was removed only by $21 \%$ after an illumination time of 180 min whereas COD abatement was found to be approximately $50 \%$ (Fig. 2(a)). It must be mentioned that the COD and the DOC of the treated samples is practically equivalent with the COD and DOC of the wastewater matrix considering the low concentrations of the antibiotics added (each compound at concentration of $100 \mu \mathrm{L} \mathrm{L}^{-1}$ produce no more than $0.1 \mathrm{mg} \mathrm{L}^{-1}$ of DOC).

Additional experiments were conducted in order to determine the efficiency of the solar photo-Fenton process without modifying the $\mathrm{pH}$ of the wastewater. The experiments were performed at the inherent $\mathrm{pH}$ value $(\mathrm{pH} \approx 7.0$ ) of the wastewater. This provides the advantage of avoiding the wastewater acidification which means additional cost through the consumption of reagents $\left(\mathrm{H}_{2} \mathrm{SO}_{4}\right)$ and subsequent increase of the salinity of the treated water (Malato et al., 2009). Fig. 2(b) shows the degradation profile of the substrates in neutral $\mathrm{pH}$ along with the degradation curves achieved under acidic conditions. It was demonstrated that the substrates in neutral $\mathrm{pH}$ were also completely removed at the end of the treatment; however, the degradation proceeded with much lower rate at neutral $\mathrm{pH}$ compared to that observed under acidic conditions. The complete degradation of the substrates was achieved at $t_{30 \mathrm{WT}, n}=48.9 \mathrm{~min}$ for OFX and at $t_{30 \mathrm{wT}, n}=47.2 \mathrm{~min}$ for TMP. The DOC declined from $8.6 \mathrm{mg} \mathrm{L}^{-1}$ to $7.5 \mathrm{mg} \mathrm{L}^{-1}$ corresponding to $12 \%$ removal of the organic matter. Table 2 summarizes the results derived from the solar photoFenton experiments under acidic and neutral conditions. Klamerth et al. (2010) determine the degradation of various micropollutants (including antibiotics) without modifying the $\mathrm{pH}$ of the wastewater. The complete degradation of most
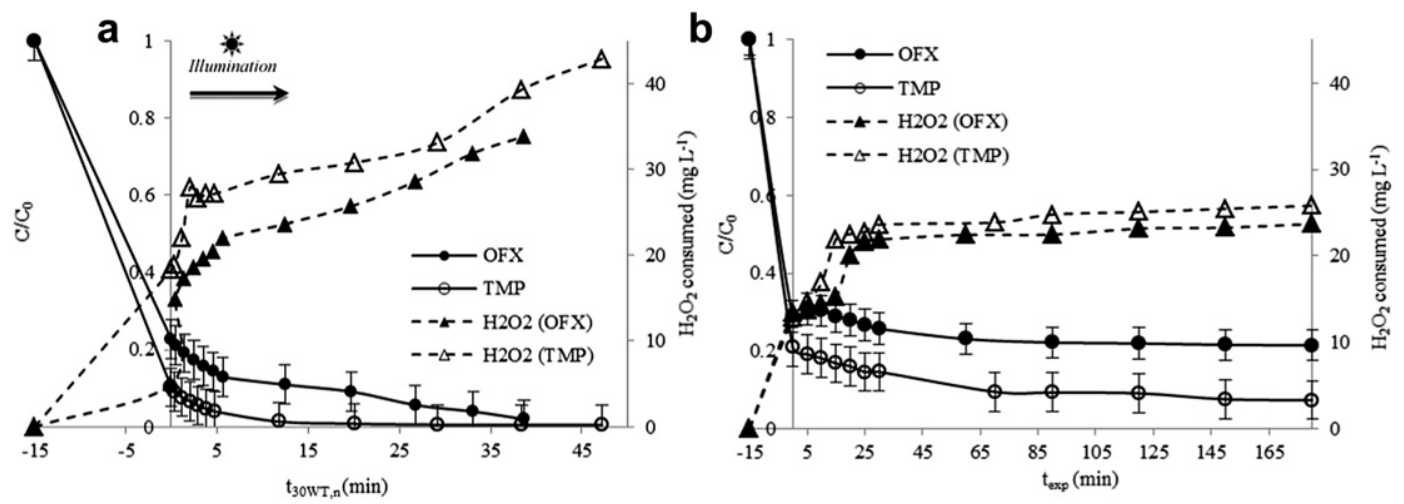

Fig. 1 - OFX and TMP degradation during: (a) Solar photo-Fenton and (b) Dark Fenton experiments. Experimental conditions: $[\text { Substrate }]_{0}=100 \mu \mathrm{g} \mathrm{L}^{-1} ;\left[\mathrm{Fe}^{2+}\right]_{0}=5 \mathrm{mg} \mathrm{L}^{-1} ;\left[\mathrm{H}_{2} \mathrm{O}_{2}\right]_{0}=75 \mathrm{mg} \mathrm{L}^{-1} ; \mathrm{pH}_{0}=2.8-2.9$. 

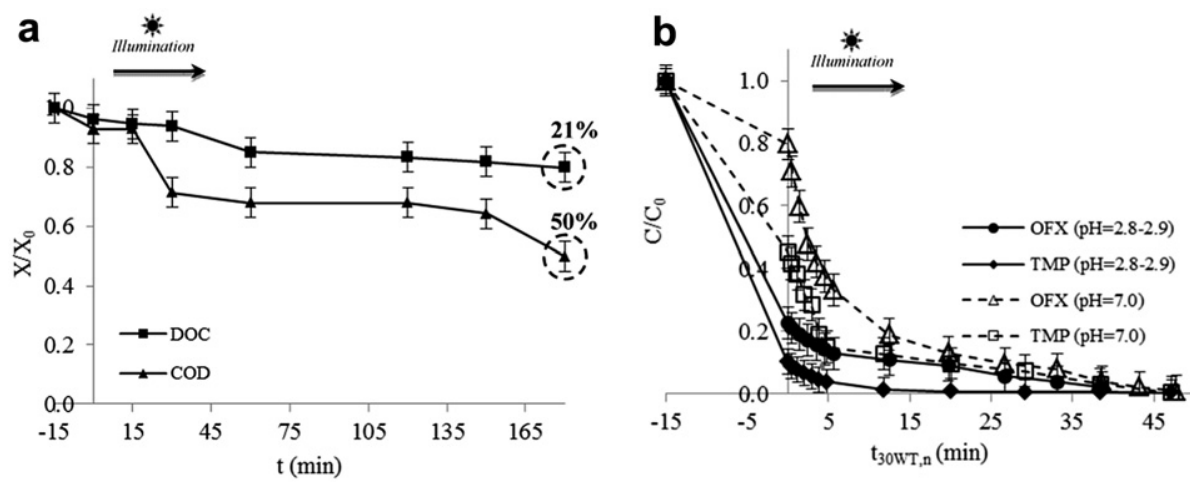

Fig. 2 - (a) Organic content removal during solar photo-Fenton process. Experimental conditions: [Substrate] $=100 \mu \mathrm{g} \mathrm{L}^{-1}$; $\left[\mathrm{Fe}^{2+}\right]_{0}=5 \mathrm{mg} \mathrm{L}^{-1} ;\left[\mathrm{H}_{2} \mathrm{O}_{2}\right]_{0}=75 \mathrm{mg} \mathrm{L}^{-1} ; \mathrm{pH}_{0}=2.8-2.9$ and (b) OFX and TMP degradation during solar photo-Fenton at acidic $(\mathrm{pH}=2.8-2.9)$ and neutral conditions.

compounds (below the LOD) was achieved within 300 min illumination time, which was however higher than the time required under acidic conditions.

The process $\mathrm{pH}$ is generally perceived as the limiting factor for the photo-Fenton system because $[\mathrm{Fe}(\mathrm{OH})]^{2+}$, the most photoactive ferric iron-hydroxy complex, is predominant at acidic $\mathrm{pH}$. In the presence of dissolved organic matter (DOM), strong and photoactive complexes are formed between ferric iron $\left(\mathrm{Fe}^{3+}\right)$ and the carboxylate or polycarboxylate groups, which are the most common functional groups in DOM (Spuhler et al., 2010). These complexes have the advantage of being soluble in the wastewater matrix and so preventing the $\mathrm{Fe}^{3+}$ precipitation at neutral $\mathrm{pH}$ conditions. Another remarkable point is that they have typically higher molar absorption coefficients in the near-UV and visible regions than the aquo$\mathrm{Fe}^{3+}$ complexes do (Pignatello et al., 2006). De la Cruz et al. (2012) proposed a mechanism which could possibly be involved in the solar photo-Fenton system in neutral $\mathrm{pH}$ and in the presence of DOM.

However, as shown in Table 2, at neutral $\mathrm{pH}$ total iron concentration decreased from $5 \mathrm{mg} \mathrm{L}^{-1}$ to approximately $3 \mathrm{mg} \mathrm{L}^{-1}$ indicating that part of the dissolved ferrous iron (which oxidized rapidly to ferric iron) precipitated during the process while iron concentration remained constant during the experiments performed under acidic conditions. This was also confirmed by conducting the following experimental procedure: two wastewater solutions at $\left[\mathrm{Fe}^{2+}\right]=5 \mathrm{mg} \mathrm{L}^{-1}$ were prepared at $\mathrm{pH} 3.0$ and 7.0. These solutions were stirred for $2 \mathrm{~h}$ and then centrifuged for $20 \mathrm{~min}$. Then, the dissolved iron in the filtered solutions was determined by atomic absorption spectroscopy. It is worth noting that during the centrifugation, a precipitate was observed in the wastewater solution at neutral $\mathrm{pH}$ indicating the formation of $\mathrm{Fe}(\mathrm{OH})_{2}$. The results showed that $45 \%$ of the dissolved ferric iron formed complexes with the DOM.

Some chelating agents have also been proposed to be used at neutral pH. Klamerth et al. (2011) employed different iron ligands for the degradation of organic pollutants during photo-Fenton at neutral $\mathrm{pH}$, such as ferrioxalate $\left(\left[\mathrm{Fe}\left(\mathrm{C}_{2} \mathrm{O}_{4}\right)_{3}\right]^{3-}\right)$ and humic acid (HA). The ferrioxalate-enhanced photo-Fenton process provided satisfactory degradation results within a reasonable time while pollutants degradation using HA was slower and nearly complete. The addition of ferrioxalate however poses an important drawback due to the increased reagents cost and its degradation during the photochemical reactions (Malato et al., 2009).

\subsection{Degradation kinetics}

Previous studies have indicated that the kinetics of pharmaceutical degradation by the photo-Fenton process is a pseudofirst order reaction (Lin et al., 2004; Radjenovic et al., 2009). Thus the concentration of the examined compounds can be given by the kinetic expression (Eq. (5)):

\section{$\mathrm{C}=\mathrm{C}_{0} e^{-k t} \quad$ (Kinetic equation 1$)$}

where $C$ and $C_{0}$ are the time-dependent concentration and the initial concentration respectively, and $k$ is the pseudo-first order rate constant.

The above expression resulted considering that the reaction between $\mathrm{HO}^{\circ}$ and the substrate (OFX or TMP) is the ratedetermining step and that $\mathrm{HO}^{*}$ rapidly achieve a constant steady-state concentration in the solution (Evgenidou et al., 2007).

The photocatalytic removal of OFX and TMP during the solar photo-Fenton process followed pseudo first-order kinetics. This was confirmed by the linear behavior of $-\ln (\mathrm{C} /$ $C_{0}$ ) as a function of the normalized time $t_{30} \mathrm{wT}, n$ in all the experiments performed $\left(R^{2}>0.99\right)$ (data not shown).

The kinetic expression (Eq. (5)) may be acceptable for a series of time-concentration data at early reaction times (usually 15-20 min). However, for wider reaction spans, this equation is unsuitable for characterizing the behavior of the irradiated system and despite the acceptable values for the correlation coefficient $\left(R^{2}\right)$ this may lead to the estimation of negative concentrations and inexistent concentration minimum values (Navarro et al., 2011). Also, Eq. (5) cannot be used for the experimental data above 15-20 min due to the competitive effects of the matrix, formation of by-products, pH changes, etc. (Evgenidou et al., 2007). When the linear approach fails, other equations can be employed. A modification of the first-order kinetic expression was proposed and has been successfully used to explain the degradation kinetics 
Table 2 - Comparison of the solar Fenton experiments performed under acidic and neutral $\mathrm{pH}$.

\begin{tabular}{lll} 
Experiment & pH 2.8-2.9 & $\begin{array}{c}\text { pH 7.0 } \\
\text { (without adjustment) }\end{array}$ \\
\hline $\mathrm{t}_{\text {30wT,n }}(\mathrm{min})^{\mathrm{a}}$ & OFX: 38.7 & OFX: 49.8 \\
& TMP: 20.1 & TMP: 47.2 \\
$\mathrm{DOC}$ removal (\%) & 21 & 12 \\
Consumed & OFX: 33.8 & OFX: 45.6 \\
$\mathrm{H}_{2} \mathrm{O}_{2}\left(\mathrm{mg} \mathrm{L}^{-1}\right)$ & TMP: 30.8 & TMP: 41.2 \\
$\begin{array}{c}\text { Total iron } \\
\left(\mathrm{mg} \mathrm{L}^{-1}\right)\end{array}$ & $4.8-5.0$ & $2.9-3.3$ \\
$\mathrm{pH}_{\text {final }}$ & & \\
\end{tabular}

a normalized illumination time for the complete degradation of the compounds.

of the compounds during the solar photo-Fenton treatment. This empirical model is described by Eq. (6).

$C=A e^{k_{1} t}+A e^{k_{2} t} \quad$ (Kinetic equation 2)

The two terms of the Eq. (6) represent the parallel conduction of two oxidation mechanism reactions during the solar photo-Fenton process possibly due to the presence of different $\mathrm{HO}^{*}$ concentration areas in solution contained in a reactor volume dV: (i) one area $\left(k_{1}\right)$ with high $\mathrm{HO}^{\circ}$ concentration due to the direct photon absorption from iron and (ii) a second area $\left(k_{2}\right)$ with lower $\mathrm{HO}^{\circ}$ concentration due to the filter inner effects or to the presence of DOM in the wastewater matrix (where $k_{1}>>k_{2}$ ). The inner filter effects present in the treated solution are considered as an important issue on the degradation rate during the solar photo-Fenton process. Inner filter effects are the competitive absorption of photons by other light absorbing species, usually the various organic contaminants present in the wastewater matrix (Malato et al., 2009). Furthermore, the presence of natural organic compounds occurring in the wastewater matrix can affect the degradation rate of the target compounds since they can exhibit significant iron complexation (or can alter the redox cycling of iron) and thereby change the formation rate of hydroxyl radicals (Lindsey and Tarr, 2000).

A model with more terms may appear to have a better fit simply because it has more parameters to be adjusted (or less degrees of freedom). In order to compare the two models and balance their different degrees of freedom the Adjusted $R^{2}$ $\left(\right.$ Adj- $R^{2}$ ) index (Perez-Moya et al., 2008) was used. This factor increases only if the addition of a new parameter improves the model more than would be expected by chance; otherwise, its value decreases.

In Table 3 the coefficient values are summarized with the respective mean square errors (MSE) of each equation calculated for each compound. The results demonstrate that the biphasic equation (Eq. (6)) fits better the experimental data (including longer times of treatment) than the usual monophasic equation (Eq. (5)). Also, the values of MSE obtained with Eq. (6) were lower for both compounds compared to that of the first-order kinetic equation. As shown in Table 3, higher values of $A d j-R^{2}$ were obtained using the kinetic equation (2); therefore kinetic equation (2) fits better the experimental data.

\subsection{Toxicity evaluation}

During the solar photo-Fenton process a number of oxidation products are formed. These products, in our case, originated from the oxidation of OFX and TMP but also from the oxidation of the DOM (DOM by-products) present in the original secondary effluent. The possible toxicity of these products was examined by two toxicity tests considering the final use of the treated wastewater. Toxicity tests using D. magna and three plant species were considered suitable to evaluate the toxicity of the treated wastewater before its disposal to water bodies and use for agricultural irrigation, respectively (Rizzo, 2011).

\subsubsection{Phytotestkit toxicity test}

Preliminary solar photo-Fenton experiments $\left(\left[\mathrm{Fe}^{2+}\right]=5 \mathrm{mg} \mathrm{L}^{-1}\right.$; $\left.\left[\mathrm{H}_{2} \mathrm{O}_{2}\right]=75 \mathrm{mg} \mathrm{L}^{-1} ; \mathrm{pH}_{0}=2.8-2.9\right)$ were performed in the absence of antibiotics in order to investigate whether the toxicity effect on the plant species is mainly due to the oxidation of the DOM. The phytotoxicity test was further conducted on samples taken from the solar photo-Fenton process (at the same reagents concentration) at various times of treatment (0-180 $\mathrm{min})$ in the presence of antibiotics. The treated samples displayed a varying toxicity profile for each type of plant by means of GI, RI and SI and the results are depicted in Table 4. It should be noted that the results are presented as a function of the actual experimental time ( $t_{\text {exp }}$ ) instead of the normalized time $\left(t_{30} \mathrm{WT}_{\mathrm{n}}\right)$ for comparison purposes among the three plant types and the two compounds.

3.4.1.1. Seed germination inhibition (GI). As can be seen in Table 4, the raw wastewater sample (WW) before the solar photo-Fenton process, caused low inhibition on germination for L. sativum (3.3\%) and S. saccharatum (3.3\%) and no inhibition for $S$. alba. The WW toxicity remained the same when the latter was spiked with $100 \mu \mathrm{g} \mathrm{L}^{-1}$ of TMP (WW + TMP) and $100 \mu \mathrm{g} \mathrm{L}^{-1}$ of OFX (WW + OFX) indicating that the presence of these antibiotics in the WW did not have any adverse effect on the seed germination. When the solar photo-Fenton was applied, the phytotoxic effects on seed germination varied among the plant species and as a function of the treatment time. The maximum GI was observed at 60 min of treatment

Table 3 - Degradation kinetics parameters for OFX and TMP using the first-order kinetic model (kinetic equation (1)) and the proposed empirical model (kinetic equation (2)).

\begin{tabular}{|c|c|c|c|c|c|c|c|c|c|}
\hline & \multicolumn{4}{|c|}{ Kinetic equation (1): $C=C_{0} e^{-k t}$} & \multicolumn{5}{|c|}{ Kinetic equation (2): $C=A e^{k_{1} t}+A e^{k_{2} t}$} \\
\hline & $\overline{C_{0}\left(\mu g L^{-1}\right)}$ & $k\left(\min ^{-1}\right)$ & Adj- $R^{2}$ & MSE & A & $k_{1}$ & $k_{2}$ & Adj- $R^{2}$ & MSE \\
\hline OFX & $18.7 \pm 0.67$ & $0.0532 \pm 5.710^{-3}$ & 0.955 & 18.2 & $10.2 \pm 0.41$ & $0.184 \pm 0.043$ & $0.0267 \pm 4.310^{-3}$ & 0.998 & 11.4 \\
\hline TMP & $10.9 \pm 0.29$ & $0.191 \pm 0.013$ & 0.939 & 1.81 & $5.61 \pm 0.12$ & $0.385 \pm 0.048$ & $0.0959 \pm 9.910^{-3}$ & 0.999 & 0.774 \\
\hline
\end{tabular}


Table 4 - Seed germination inhibition (GI), root growth inhibition (RI) and shoot growth inhibition (SI) during solar Fenton process. Experimental conditions:

$[\text { Substrate }]_{0}=100 \mu \mathrm{g} \mathrm{L}^{-1} ;\left[\mathrm{Fe}^{2+}\right]_{0}=5 \mathrm{mg} \mathrm{L}^{-1} ;\left[\mathrm{H}_{2} \mathrm{O}_{2}\right]_{0}=75 \mathrm{mg} \mathrm{L}^{-1} ; \mathrm{pH}_{0}=2.8-2.9$

\begin{tabular}{|c|c|c|c|c|c|c|c|c|c|c|}
\hline \multirow[t]{2}{*}{ Plant species } & \multirow[t]{2}{*}{ Treatment time (min) } & \multicolumn{3}{|c|}{ Germination inhibition (GI, \%) $^{\mathrm{a}}$} & \multicolumn{3}{|c|}{ Root inhibition (RI, \%) ${ }^{\mathrm{a}}$} & \multicolumn{3}{|c|}{ Shoot inhibition (SI, \%) ${ }^{\mathrm{a}}$} \\
\hline & & WW & $\mathrm{WW}+\mathrm{TMP}$ & $\mathrm{WW}+\mathrm{OFX}$ & WW & $\mathrm{WW}+\mathrm{TMP}$ & $\mathrm{WW}+\mathrm{OFX}$ & WW & $\mathrm{WW}+\mathrm{TMP}$ & $\mathrm{WW}+\mathrm{OFX}$ \\
\hline \multirow[t]{6}{*}{ Sinapis alba } & 0 & ni & ni & ni & $24.0 \pm 5.2$ & $27.2 \pm 4.7$ & $29.1 \pm 10.8$ & $24.5 \pm 11.7$ & $35.2 \pm 15.1$ & $45.4 \pm 6.2$ \\
\hline & 30 & $8.0 \pm 2.2$ & $5.0 \pm 1.6$ & $10.0 \pm 1.5$ & $30.0 \pm 4.8$ & $37.9 \pm 9.5$ & $44.4 \pm 16.1$ & $38.7 \pm 8.5$ & $39.6 \pm 8.2$ & $40.3 \pm 8.5$ \\
\hline & 60 & $10.0 \pm 5.5$ & $13.3 \pm 2.0$ & $10.0 \pm 2.5$ & $35.4 \pm 11.1$ & $52.0 \pm 13.2$ & $42.4 \pm 8.2$ & $47.6 \pm 13.1$ & $48.5 \pm 5.7$ & $47.9 \pm 8.9$ \\
\hline & 120 & $5.0 \pm 1.8$ & $10.0 \pm 1.5$ & $4.0 \pm 1.8$ & $40.2 \pm 6.8$ & $56.3 \pm 10.8$ & $46.2 \pm 12.2$ & $55.0 \pm 9.3$ & $54.6 \pm 9.2$ & $64.2 \pm 11.3$ \\
\hline & 150 & $3.3 \pm 2.1$ & $3.3 \pm 1.9$ & ni & $20.2 \pm 12.2$ & $29.7 \pm 15.2$ & $33.2 \pm 9.6$ & $42.5 \pm 5.9$ & $44.0 \pm 10.1$ & $37.3 \pm 10.7$ \\
\hline & 180 & ni & ni & ni & $15.1 \pm 9.7$ & $18.5 \pm 7.9$ & $10.7 \pm 17.7$ & $25.3 \pm 5.1$ & $33.7 \pm 11.5$ & $32.5 \pm 9.2$ \\
\hline \multirow[t]{6}{*}{ Lepidium sativum } & 0 & $3.3 \pm 0.0$ & $3.3 \pm 1.5$ & $3.3 \pm 0.0$ & $28.3 \pm 9.9$ & $35.7 \pm 14.3$ & $31.0 \pm 12.1$ & $43.1 \pm 9.2$ & $46.6 \pm 5.9$ & $44.6 \pm 8.7$ \\
\hline & 30 & $20 \pm 2.9$ & $13.3 \pm 1.8$ & $23.3 \pm 3.9$ & $31.3 \pm 7.2$ & $28.9 \pm 9.5$ & $42.7 \pm 9.3$ & $45.1 \pm 13.2$ & $44.4 \pm 9.9$ & $44.9 \pm 13.9$ \\
\hline & 60 & $10 \pm 1.9$ & $6.7 \pm 2.6$ & $10 \pm 1.5$ & $32.5 \pm 5.5$ & $35.7 \pm 9.0$ & $37.8 \pm 6.9$ & $40.2 \pm 9.4$ & $41.3 \pm 10.4$ & $51.9 \pm 11.4$ \\
\hline & 120 & $3.3 \pm 1.9$ & $3.3 \pm 1.5$ & $3.3 \pm 2.0$ & $35.3 \pm 13.2$ & $45.0 \pm 17.2$ & $31.9 \pm 10.1$ & $44.8 \pm 7.6$ & $43.8 \pm 10.8$ & $54.5 \pm 15.1$ \\
\hline & 150 & $3.3 \pm 0.0$ & $3.3 \pm 0.5$ & $3.3 \pm 0.2$ & $21.8 \pm 18.3$ & $29.8 \pm 11.7$ & $28.8 \pm 15.5$ & $37.9 \pm 5.8$ & $39.9 \pm 7.9$ & $36.9 \pm 5.8$ \\
\hline & 180 & ni & ni & ni & $23.7 \pm 11.2$ & $23.3 \pm 8.6$ & $22.1 \pm 8.9$ & $30.0 \pm 5.0$ & $31.6 \pm 3.2$ & $28.0 \pm 6.4$ \\
\hline \multirow[t]{6}{*}{ Sorghum saccharatum } & 0 & $3.3 \pm 0.0$ & $3.3 \pm 0.0$ & $3.3 \pm 0.0$ & $32.8 \pm 5.6$ & $38.8 \pm 8.9$ & $55.7 \pm 11.2$ & $62.7 \pm 13.2$ & $67.4 \pm 9.9$ & $63.4 \pm 11.6$ \\
\hline & 30 & $6.7 \pm 1.8$ & $3.3 \pm 0.0$ & $3.3 \pm 1.0$ & $33.0 \pm 8.2$ & $28.3 \pm 10.1$ & $50.5 \pm 8.9$ & $67.6 \pm 10.1$ & $65.6 \pm 13.2$ & $75.2 \pm 9.1$ \\
\hline & 60 & $3.3 \pm 1.6$ & ni & $3.3 \pm 1.8$ & $38.23 \pm 7.9$ & $47.2 \pm 12.5$ & $52.5 \pm 10.7$ & $73.0 \pm 9.3$ & $71.3 \pm 15.9$ & $76.3 \pm 14.4$ \\
\hline & 120 & $3.3 \pm 1.5$ & $6.7 \pm 0.7$ & ni & $42.15 \pm 11.3$ & $47.9 \pm 5.9$ & $41.7 \pm 10.4$ & $75.0 \pm 9.8$ & $79.5 \pm 10.5$ & $84.6 \pm 12.8$ \\
\hline & 150 & $5.0 \pm 0.9$ & ni & $6.7 \pm 2.5$ & $45.3 \pm 9.5$ & $32.8 \pm 5.5$ & $38.0 \pm 11.2$ & $64.0 \pm 8.9$ & $61.1 \pm 9.8$ & $57.2 \pm 9.2$ \\
\hline & 180 & ni & ni & ni & $30.2 \pm 4.8$ & $29.2 \pm 7.1$ & $26.8 \pm 8.3$ & $45.7 \pm 7.7$ & $46.3 \pm 10.2$ & $46.9 \pm 7.6$ \\
\hline
\end{tabular}

ni: no inhibition

a Values(\%) $\pm \mathrm{RSD}(\%)$ in relation to that in tap water. 
for S. alba (10\%) whereas for L. sativum and S. saccharatum the maximum GI values were 20 and $6.7 \%$ respectively after $30 \mathrm{~min}$ of treatment. At the end of the treatment $(180 \mathrm{~min})$ the GI was eliminated for all the plant species.

In the case of the wastewater spiked with TMP, a maximum inhibition to L. sativum (13.3\%) was observed after 30 min of solar photo-Fenton treatment due to the subsequent formation of by-products which apparently were toxic to these seeds. The L. sativum germination inhibition was decreased by increasing the irradiation time from 60 to $150 \mathrm{~min}$, while no inhibition was detected after $180 \mathrm{~min}$ of treatment meaning that less toxic intermediates were formed at the end of the process. Additionally, at 60 and $120 \mathrm{~min}$ of treatment a maximum inhibition to $S$. alba (13.3\%) and $S$. saccharatum (6.7\%) was observed respectively whereas no negative effect on germination was achieved at the end of the treatment (180 $\mathrm{min}$ ) for both species.

In the case of OFX, L. sativum displayed similar germination inhibition profile compared to that observed for TMP. The higher inhibition (23.3\%) was observed after $30 \mathrm{~min}$ of treatment. S. alba germination inhibition was $10 \%$ at 30 and $60 \mathrm{~min}$ of treatment whereas the highest inhibition of S. saccharatum was $6.7 \%$ after $150 \mathrm{~min}$ of solar photo-Fenton. Finally the inhibition on seed germination was eliminated after 180 min of irradiation for each type of plant.

In summary, the GI results obtained from the treated wastewater spiked with the antibiotics at $100 \mu \mathrm{g} \mathrm{L}^{-1}$ were quite similar with those observed when exposing the plant species to the wastewater treated samples alone; therefore it can be concluded that the seed germination is not affected by the presence of these antibiotics and their by-products at the $\mu \mathrm{g} \mathrm{L}^{-1}$ concentration level. The differences in the data obtained, can be attributed to the potential differences of the quality characteristics of the wastewater used during the experimental period.

3.4.1.2. Root inhibition (RI). The phytotoxicity in the treated samples expressed as root growth inhibition (RI), varied differently compared to the seed germination (GI). The percentage effect of the treated samples on RI was higher compared to that observed on GI. Some research studies which investigated the phytotoxicity of sewage sludges (Wong et al., 2001; Fuentes et al., 2006; Rizzo, 2011) pointed out the fact that the evaluation of root length is a more sensitive parameter than seed germination.

As shown in Table 4, a similar inhibition evolution on the root length compared to the raw wastewater (WW) was observed after spiking the wastewater with the antibiotics (WW + TMP, WW + OFX). This was confirmed by applying the student $t$-test between the measured values where no statistical differences were observed. These results indicated that the low spiked concentration level of these antibiotics $\left(100 \mu \mathrm{g} \mathrm{L}^{-1}\right)$ did not impose any adverse effect on root growth. However, the stimulating effect to the seeds of nutrients occurring in wastewater may still prevail considering the fact that the WW contains high concentration of nitrates (36 $\mathrm{mg} \mathrm{L}^{-1}$, see Table 2) which are considered very important for the root development (Rizzo et al., 2009). The maximum RI observed in the case of WW alone were $40.2,35.3$ and $42.3 \%$ for S. alba, L. sativum and S. saccharatum, respectively.
The RI of S. alba in wastewater spiked with TMP was increased at 30, 60 and $120 \mathrm{~min}$ of the photocatalytic treatment yielding $37.9 \%, 52.0 \%$ and $56.3 \%$ of inhibition, respectively. Finally, samples irradiated for 150 and 180 min resulted in less toxicity displaying a decrease on RI $(29.7 \%$ and $18.5 \%$ respectively) indicating the removal or transformation of the toxic by-products throughout the process. In the case of $L$. sativum and S. saccharatum the root length inhibition showed approximately the same tendency. At the end of the process the RI was decreased yielding $23.3 \%$ and $29.2 \%$ root inhibition for L. sativum and S. saccharatum respectively.

In the case of OFX, the RI for S. alba was increased after 30 min of treatment (44.4\%) and remained almost constant until 120 min while it was significantly decreased (10.6\%) after 180 min of irradiation. In the case of L. sativum, RI was slightly increased during the process and dropped at the end of the treatment $(24.1 \%$ at $18 \mathrm{~min})$ to the same level as the WW alone. For S. saccharatum the RI was continuously decreasing through the process to reach the level values of the WW alone.

Interestingly however, was the fact that the RI values observed at the end of the treatment (150 and $180 \mathrm{~min}$ ) were approximately the same in all cases (TMP, OFX, WW) indicating that the negative effect on the root growth is attributed to the DOM by-products rather than the substrates oxidation by-products.

Some other studies showed the negative effect of antibiotics at the $\mu \mathrm{g} \mathrm{L}^{-1}$ level on the root growth (Migliore et al., 2003). Phytotoxicity of enrofloxacin on crop plants Cucumis sativus, Lactuca sativa, Phaseolus vulgaris and Raphanus sativus was determined at 50,100 and $5000 \mu \mathrm{g} \mathrm{L}^{-1}$ by measuring postgerminative growth of primary root. The exposure to lower concentrations of enrofloxacin (50 and $100 \mu \mathrm{g} \mathrm{L}^{-1}$ ) was found to cause alteration of the post-germinative development which is related to the plant drug uptake.

3.4.1.3. Shoot inhibition (SI). Similar SI profile was observed in the case of WW alone and WW spiked with the antibiotics indicating that the SI was affected presumably by the DOM byproducts. In the case of TMP, S. alba SI showed similarities with the RI, however the SI at the end of the process was higher compared to that of RI. The highest SI was $54.6 \%$ after 120 min (similar to the RI, 56.3\%) whereas after $180 \mathrm{~min}$ the SI decreased to $43.7 \%$. Similar behavior was observed for the S. saccharatum however in this case the SI values were higher than the respective values of RI. The SI from $79.5 \%$ after $120 \mathrm{~min}$ of treatment reduced to $46.3 \%$ after $180 \mathrm{~min}$. In the case of L. sativum no significant changes were obtained during the process; however at the end of the treatment the SI was by $15 \%$ lower than the initial value indicating the efficiency of the process to remove the toxic compounds. Similar results were obtained in the case of OFX.

The results described above demonstrated the capacity of the applied advanced process to reduce the phytotoxicity to the examined plant species. The three plant species displayed an interesting profile concerning the germination, root and shoot inhibition stimulated by the presence of oxidation byproducts. According to our knowledge, there is limited literature dealing with phytotoxicity assays although it is important considering the use of the treated domestic wastewater for agricultural purposes. 
Naddeo et al. (2009) studied the ecotoxicity to L. sativum before and after the ultrasonic irradiation treatment in urban wastewater effluent spiked with pharmaceuticals (diclofenac, amoxicillin and carbamazepine). It was found that the inhibition of L. sativum in terms of germination was stimulated instead of inducing any toxicity effect and this might be attributed to the fact that the samples, spiked with very low drug concentrations, were able to act as a provider of additional nutrient elements. In another study of Rizzo et al. (2009) the photocatalytic effect $\left(\mathrm{TiO}_{2}\right.$ process) on $\mathrm{L}$. sativum germination using both spiked distilled water and actual wastewater solutions with pharmaceuticals (diclofenac, amoxicillin and carbamazepine) was investigated. The photocatalytic treatment did not completely reduce the phytotoxicity under the investigated conditions $\left(\left[\mathrm{TiO}_{2}\right]=0.8 \mathrm{~g} \mathrm{~L}^{-1} ; 120\right)$ and a drastic decrease in germination was observed, indicating the formation of toxic oxidation intermediates which were toxic to L. sativum seeds.

\subsubsection{D. magna toxicity test}

In all the tests performed (WW with and without the antibiotics), solar photo-Fenton process was observed to induce the same variation in the toxicity profile (expressed as \% immobilization) indicating that the presence of OFX and TMP (and their by-products) at the low concentration level of $\mu \mathrm{g} \mathrm{L}^{-1} \mathrm{did}$ not affect $D$. magna species. It should be noted that previous studies revealed toxic effects of these antibiotics to D. magna at higher concentration level $\left(>10 \mathrm{mg} \mathrm{L}^{-1}\right)$ though (Isidori et al., 2005; Kim et al., 2007; Hapeshi et al., 2010). The results are depicted in Fig. 3.

Primarily, in order to determine the toxicity of the secondary treated wastewater (WW) used for the whole experimental procedure, toxicity tests were performed by exposing D. magna to the wastewater samples. These tests showed no toxicity to D. magna after 24 h exposure; however after $48 \mathrm{~h}$ of exposure the immobilization of daphnids increased to $13.3 \pm 0.8 \%$.

The toxicity of the treated samples taken after $30 \mathrm{~min}$ of the photocatalytic process was dramatically increased to
$40 \pm 0.2 \%$ and $60 \pm 0.4 \%$ after 24 and $48 \mathrm{~h}$ of exposure respectively. The increment is attributed to the rapidly formed organic intermediates from the oxidation of the DOM.

After 60 min of treatment, an immobilization decreased was observed (which means that the oxidation of the by-products formed at $30 \mathrm{~min}$ and consequently the formation of new intermediates was still going on) but increased again after $120 \mathrm{~min}$ of treatment indicating the formation of less toxic oxidation by-products. This may attributed to the competition mechanisms related to the degradation of organics (including the antibiotics), the complete oxidation of organics to $\mathrm{CO}_{2}$ and the formation of the toxic compounds. From that time and onwards a continuous decrease was observed. After $150 \mathrm{~min}$ of irradiation a significant decrease on immobilization after $24 \mathrm{~h}$ of exposure $(25 \pm 1 \%)$ was observed due to the potential formation of less toxic by-products. Finally, after $180 \mathrm{~min}$ of photo-treatment the immobilization of daphnids after $24 \mathrm{~h}$ of exposure was $13.3 \pm 0.6 \%$ while after $48 \mathrm{~h}$ of exposure the respective value was $33.3 \pm 0.7 \%$.

Since the toxicity of the treated samples after $180 \mathrm{~min}$ of solar photo-Fenton process was higher than that of the untreated wastewater, additional experiments were carried out to investigate whether the residual toxicity could be reduced in longer treatment time. The results showed a decrease in daphnids immobilization (6.7\%) after $300 \mathrm{~min}$ indicating the removal of the toxic compounds.

\subsection{Antibiotic resistant enterococci bacteria removal}

Enterococci are lactic acid bacteria associated with enteric systems and are relevant indicators of fecal contamination. Given their ubiquity and close contact with humans, enterococci are also considered important vectors of antibiotic resistance (European Antimicrobial Resistance Surveillance SystemEARSS). Moreover, these bacteria are implicated in a wide variety of human diseases, with urinary tract infections being the most common while bacteraemia/endocarditis being the most severe (Blanch et al., 2003; Cattoir et al., 2009). These bacteria are released into the environment via wastewater

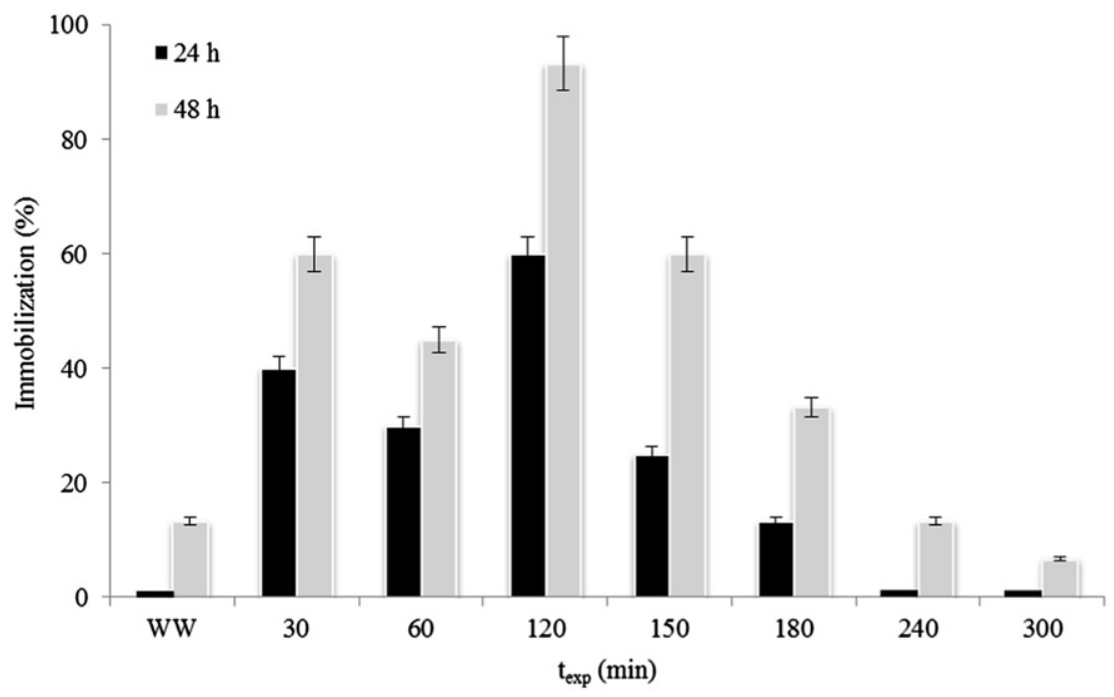

Fig. 3 - Evolution of toxicity to D. magna during solar photo-Fenton process. Experimental conditions: $[\text { Substrate }]_{0}=100 \mu \mathrm{g} \mathrm{L}^{-1} ;\left[\mathrm{Fe}^{2+}\right]_{0}=5 \mathrm{mg} \mathrm{L}^{-1} ;\left[\mathrm{H}_{2} \mathrm{O}_{2}\right]_{0}=75 \mathrm{mg} \mathrm{L}^{-1} ; \mathrm{pH}_{0}=2.8-2.9$. 

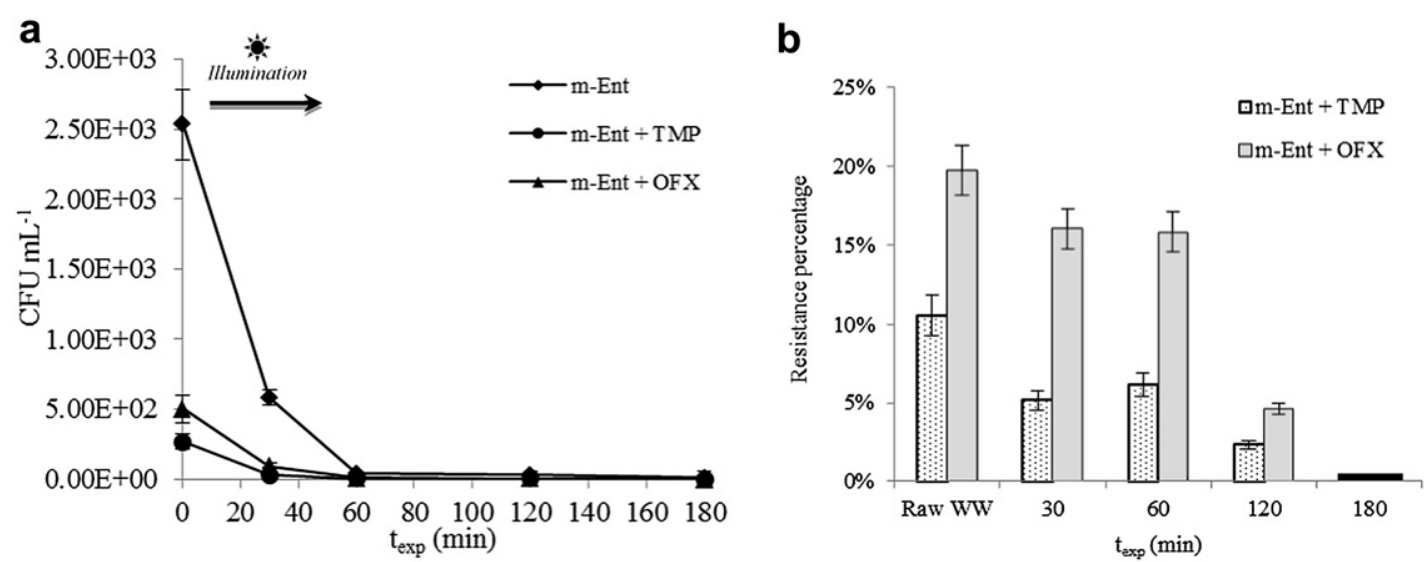

Fig. 4 - (a) Number of enterococci (bacterial density expressed as CFU mL ${ }^{-1}$ ) present in the treated samples and (b) Antibiotic resistance evolution during the solar photo-Fenton process.

effluents and are often used as indicators of microbial quality in waters. Among the trimethoprim-resistant bacteria, enterococci remain the least studied, probably due to the controversial role of TMP as a therapeutic option (Hamilton-Miller, 1988; Murray, 1989). In addition, TMP analogs developed in recent years have demonstrated good activity against enterococci.

The average bacterial density of enterococci in the examined samples expressed in CFU $\mathrm{mL}^{-1}$ against the treatment time is shown in Fig. 4(a) whereas Fig. 4(b) depicts the average resistance percentage profile during the process. It was observed that enterococci presented significantly lower counts in the solar photo-Fenton treated samples compared to the untreated wastewater effluent sample. The average of enterococci population in the initial wastewater sample was $2.53 \times 10^{3}$ whereas the bacteria population was eliminated at the end of the treatment $\left(t_{\exp }=180 \mathrm{~min}\right)$. Comparing the resistance rates for the two antibiotics tested, it was observed that OFX resistance was almost double of that of TMP. This is in agreement with previous studies which report high quinolone resistance in the species Enterococcus faecium and E. faecalis, the most frequent species of enterococci in wastewaters (Ferreira da Silva et al., 2006).

At $\mathrm{pH}$ around 3, most microorganisms are inactivated (Malato et al., 2009). Moreover, $\mathrm{H}_{2} \mathrm{O}_{2}$ and iron can migrate inside the bacteria cells and cause damage to cell functions by catalyzing the production of reactive oxygen radicals. Additionally, the synergistic effect of hydrogen peroxide and solar photons leads to the inactivation and death of bacteria.

It should be noted that the studies conducted so far in the area of advanced wastewater treatment dealt with the disinfection efficiency and not with the removal of the antibiotic resistant bacteria. Over the past several years, there has been a growing interest in the application of solar photo-Fenton for water disinfection, with Escherichia coli being the most widely investigated bacterium. Pulgarin and co-workers showed that the inactivation of $E$. coli under sunlight could be enhanced by adding $\mathrm{Fe}^{2+}$ or $\mathrm{Fe}^{3+}$ and $\mathrm{H}_{2} \mathrm{O}_{2}$. They also showed that some organic and inorganic molecules in the water matrix were responsible for the reduced disinfection efficiency of photo-Fenton (Rincón and Pulgarin, 2005). Spuhler et al. (2010) proved that solar photo-Fenton system at low concentrations of reagents $\left(0.6 \mathrm{mg} \mathrm{L}^{-1}\right.$ of $\mathrm{Fe}^{2+}, 10 \mathrm{mg} \mathrm{L}^{-1} \mathrm{H}_{2} \mathrm{O}_{2}$ ) and at near neutral $\mathrm{pH}$ was efficient for $\mathrm{E}$. coli bacterial inactivation.

\subsection{Economic evaluation for the photocatalytic process}

There is limited literature dealing with wastewater treatment process economics although this aspect is very important issue (Hernández-Sancho et al., 2010; Jordá et al., 2011). Based on the experimental and operational data recorded during the operational period of the solar pilot plant unit and on the basic design parameters applied, a scale up extrapolation was carried out. The aim of this task was to establish the overall cost for a full scale installation operating for a period of 5 years. For this purpose, a simple methodology was developed based on the investment cost estimation along with the operational (including mainly electric power and consumables) and the maintenance cost. The size of the scale up plant is based on a capacity to serve 1000 pe community.

Energy consumption estimation ( $\mathrm{kWh}$ ) was based on the electrical power consumption (kW) (mainly pumping) multiplied by the operating time (in hours). The projected power consumption cost is $10.703,50 €$ for 5 years. The per day costs of $\mathrm{H}_{2} \mathrm{O}_{2}, \mathrm{FeSO}_{4} .7 \mathrm{H}_{2} \mathrm{O}, \mathrm{H}_{2} \mathrm{SO}_{4}$ are $0.338,13.5$ and $1.5 €$, respectively. The maintenance cost (inspection, replacement and repair) were estimated as a percentage of the total investment cost. For this type of plants $1.5 \%$ of the initial investment cost per annum can be considered representative. This approach gives an annual maintenance cost of $15.198,75 €$ over the period of 5 years.

The total cost of the full scale unit for the treatment of $150 \mathrm{~m}^{3}$ day $^{-1}$ (corresponding to $1000 \mathrm{pe}$ ) secondary wastewater effluent was found to be $0.85 € \mathrm{~m}^{-3}$. This value is in agreement with a previous study of the photo-Fenton process in a pilot scale set-up (Jordá et al., 2011).

\section{Conclusions}

- The pilot scale experiments showed that OFX and TMP at low concentration level ( $\mu \mathrm{g} \mathrm{L}^{-1}$ range) can be successfully degraded with solar photo-Fenton at low 
iron concentration $\left(5 \mathrm{mg} \mathrm{L}^{-1}\right)$ and low initial $\mathrm{H}_{2} \mathrm{O}_{2}$ (75 $\mathrm{mg} \mathrm{L}^{-1}$ ) concentration.

- The photocatalytic removal of OFX and TMP with the solar photo-Fenton process followed apparent firstorder kinetics whereas modification of the first-order kinetic expression has been successfully used to explain the degradation kinetics of the compounds during the photo-Fenton treatment.

- Solar photo-Fenton process did not exert any significant influence on seed germination which was found to be affected by the DOM by-products and not by the presence of the antibiotics and their by-products at the $\mu \mathrm{g} \mathrm{L}^{-1}$ concentration level. GI was eliminated at the end of the treatment for each type of plant. Root growth on the other hand, was more sensitive and was affected by the organic by-products formed during the oxidation of both the parent compounds and DOM. Shoot growth inhibition was affected mainly by the DOM by-products. RI and SI were decreased at the end of the treatment.

- The presence of OFX and TMP (and their by-products) at the $\mu \mathrm{g} \mathrm{L}^{-1}$ level did not affect $D$. magna species and the toxicity changes were attributed to the DOM byproducts. The toxicity to daphnids was decreased within 300 min compared to the untreated wastewater.

- Solar photo-Fenton process contributed significantly to the prevalence of enterococci, including those resistant to TMP or OFX, in the treated samples. The release of antibiotic resistant bacteria and genes in the aquatic environment through the wastewater discharges is an issue of major concern nowadays. This study demonstrated the efficiency of solar photo-Fenton to remove resistant enterococci. However, more studies are needed in order to examine the efficiency of such processes with regard to the removal of other bacteria and genes.

- Solar photo-Fenton was proved to be an efficient and cost effective method considering the need for wastewater reuse for agriculture irrigation purposes, and thus the need for wastewater free from antibiotics.

\section{Acknowledgments}

The experimental work was co-funded by the European Regional Development Fund and the Republic of Cyprus through the Research Promotion Foundation (Strategic Infrastructure Project NEAYחO $\triangle O M H / \Sigma T P A T H / 0308 / 09)$. Part of this work was also funded by COST (European Cooperation in Science and Technology) through a Short Term Scientific Mission (STSM) within the COST scientific programme on "Detecting evolutionary hot spots of antibiotic resistances in Europe (DARE)".

\section{R E F E R E N C E S}

Akiyama, T., Savin, M.C., 2010. Populations of antibiotic-resistant coliform bacteria change rapidly in a wastewater effluent dominated stream. Science of the Total Environment 408, 6192-6201.

Andreozzi, R., Caprio, V., Insola, A., Marotta, R., 1999. Advanced oxidation processes (AOP) for water purification and recovery. Catalysis Today 53, 51-59.

Andrews, J.M., 2009. BSAC standardized disc susceptibility testing method (version 8). Journal of Antimicrobial Chemotherapy 64, 454-489.

Barbarin, N., Henion, J.D., Wu, Y., 2002. Comparison between liquid chromatography-UV detection and liquid chromatography-mass spectrometry for the characterization of impurities and/or degradants present in trimethoprim tablets. Journal of Chromatography A 970, 141-154.

Blanch, A.R., Caplin, J.L., Iversen, A., Kuhn, I., Manero, A., Taylor, H.D., Vilanova, X., 2003. Comparison of enterococcal populations related to urban and hospital wastewater in various climatic and geographic European regions. Journal of Applied Microbiology 94, 994-1002.

Castiglioni, S., Pomati, F., Miller, K., Burns, B.P., Zuccato, E., Calamari, D., Neilan, B.A., 2008. Novel homologs of the multiple resistance regulator marA in antibioticcontaminated environments. Water Research 42, 4271-4280.

Cattoir, V., Huynh, T.M., Bourdon, N., Auzou, M., Leclercq, R., 2009. Trimethoprim resistance genes in vancomycinresistant Enterococcus faecium clinical isolates from France. International Journal of Antimicrobial Agents 34 (4), 390-392.

Clesceri, L.S., Greenberg, A.E., Eaton, A.D., 1998. Standard Methods for the Examination of Water and Wastewater, twentieth ed. American Public Health Association, American Water Works Association, Water Environment Federation, Baltimore, Maryland.

Cyprus Law on the Pollution of Water Bodies: 106(I)/2002.

De la Cruz, N., Giménez, J., Esplugas, S., Grandjean, D., de Alencastro, L.F., Pulgarín, C., 2012. Degradation of 32 emergent contaminants by UV and neutral photo-Fenton in domestic wastewater effluent previously treated by activated sludge. Water Research 46, 1947-1957.

Evgenidou, E., Konstantinou, I., Fytianos, K., Poulios, I., 2007. Oxidation of two organophosphorous insecticides by the photo-assisted Fenton reaction. Water Research 41, 2015-2027.

Ferreira da Silva, M., Tiago, I., Verissimo, A., Boaventura, R.A.R., Nunes, O.C., Manaia, C.M., 2006. Antibiotic resistance of enterococci and related bacteria in an urban wastewater treatment plant. FEMS Microbial Ecology 55, 322-329.

Fuentes, A., Lorens, M., Saez, J., Aguilar, M.I., Pe'rez-Marin, A.B., Ortuno, J.F., Meseguer, V.F., 2006. Ecotoxicity, phytotoxicity and extractability of heavy metals from different stabilized sewage sludges. Environmental Pollution 143, 355-360.

Gernjak, W., Fuerhacker, M., Fernández-Ibanez, P., Blanco, J., Malato, S., 2006. Solar photo-Fenton treatment-process parameters and process control. Applied Catalysis B: Environmental 64, 121-130.

Hamilton-Miller, J.M.T., 1988. Reversal of activity of trimethoprim against gram-positive cocci by thymidine, thymine and "folates". Journal of Antimicrobial Chemotherapy 22, 35-39.

Hapeshi, E., Achilleos, A., Vasquez, M.I., Michael, C., Xekoukoulotakis, N.P., Mantzavinos, D., Kassinos, D., 2010. Drugs degrading photocatalytically: kinetics and mechanisms of ofloxacin and atenolol removal on titania suspensions. Water Research 44 (6), 1737-1746.

Hernández-Sancho, F., Molinos-Senante, M., Sala-Garrido, R., 2010. Economic valuation of environmental benefits from wastewater treatment processes: an empirical approach for Spain. Science of the Total Environment 408, 953-957.

Isidori, M., Lavorgna, M., Nardelli, A., Pascarella, L., Parrella, A., 2005. Toxic and genotoxic evaluation of six antibiotics on 
non-target organisms. Science of the Total Environment 346, 87-98.

ISO 6341:1996. Water Quality-Determination of the Inhibition of the Mobility of Daphnia magna Straus (Cladocera, Crustacea)Acute Toxicity Test.

Jordá, L.S.J., Martín, M.M.B., Gómez, E.O., Reina, A.C., Sánchez, I.M.R., López, J.L.C., Pérez, J.A.S., 2011. Economic evaluation of the photo-Fenton process. Mineralization level and reaction time: the keys for increasing plant efficiency. Journal of Hazardous Materials 186, 1924-1929.

Kim, Y., Choi, K., Jung, J., Park, S., Kim, P.G., Park, J., 2007. Aquatic toxicity of acetaminophen, carbamazepine, cimetidine, diltiazem and six major sulfonamides, and their potential ecological risks in Korea. Environment International 33, 370-375.

Klamerth, N., Malato, S., Maldonado, M.I., Agüera, A., FernándezAlba, A., 2011. Modified photo-Fenton for degradation of emerging contaminants in municipal wastewater effluents. Catalysis Today 161, 241-246.

Klamerth, N., Rizzo, L., Malato, S., Maldonado, M.I., Aguera, A., Fernández-Alba, A.R., 2010. Degradation of fifteen emerging contaminants at $\mu \mathrm{g} \mathrm{L}^{-1}$ initial concentrations by mild solar photo-Fenton in MWTP effluents. Water Research 44, 545-554.

Kümmerer, K., 2009. Antibiotics in the aquatic environment a review-part I. Chemosphere 75, 417-434.

Li, B., Zhang, T., 2011. Mass flows and removal of antibiotics in two municipal wastewater treatment plants. Chemosphere. http://dx.doi.org/10.1016/j.chemosphere.2011.03.002.

Li, N., Zhang, Y.H., Xiong, X.L., Li, Z.G., Jin, X.H., Wu, Y.N., 2005. Study of the physicochemical properties of trimethoprim with $\beta$-cyclodextrin in solution. Journal of Pharmaceutical and Biomedical Analysis 38, 370-374.

Lin, K., Yuan, D., Chen, M., Deng, Y., 2004. Kinetics and products of photo-Fenton degradation of Triazophos. Journal of Agriculture and Food Chemistry 52, 7614-7620.

Lindsey, M.E., Tarr, M.A., 2000. Quantitation of hydroxyl radical during Fenton oxidation following a single addition of iron and peroxide. Chemosphere 41, 409-417.

Malato, S., Fernández-Ibáñez, P., Maldonado, M.I., Blanco, J., Gernjak, W., 2009. Decontamination and disinfection of water by solar photocatalysis: recent overview and trends. Catalysis Today 147, 1-59.

Michael, I., Hapeshi, E., Michael, C., Fatta-Kassinos, D., 2010. Solar Fenton and solar $\mathrm{TiO}_{2}$ catalytic treatment of ofloxacin in secondary treated effluents: evaluation of operational and kinetic parameters. Water Research 44, 5450-5462.

Michael, I., Hapeshi, E., Michael, C., Fatta-Kassinos, D., 2012. Development and validation of a UPLC-MS/MS method forstudying the degradation kinetics of ofloxacin andtrimethoprim during the application of solar Fenton process in secondary treated sewage. Water Science and Technology 66, 1574-1581.

Migliore, L., Cozzolino, S., Fiori, M., 2003. Phytotoxicity to and uptake of enrofloxacin in crop plants. Chemosphere 52, 1233-1244.

Murray, B.E., 1989. Antibiotic treatment of enterococcal infection. Antimicrobial Agents and Chemotherapy 33, 1411.

Naddeo, V., Meric, S., Kassinos, D., Belgiorno, V., Guida, M., 2009. Fate of pharmaceuticals in contaminated urban wastewater effluent under ultrasonic irradiation. Water Research 43, 4019-4027.

Nau, R., Kinzig, M., Dreyhaupt, T., Kolenda, H., Sorgel, F., Prange, H.W., 1994. Kinetics of ofloxacin and its metabolites in cerebrospinal fluid after a single intravenous infusion of 400 milligrams of ofloxacin. Antimicrobial Agents and Chemotherapy 38 (8), 1849-1853.

Navarro, S., Fenoll, J., Vela, N., Ruiz, E., Navarro, G., 2011. Removal of ten pesticides from leaching water at pilot plant scale by
photo-Fenton treatment. Chemical Engineering Journal 167, 42-49.

Nogueira, R.F.P., Oliveira, M.C., Paterlini, W.C., 2005. Simple and fast spectrophotometric determination of $\mathrm{H}_{2} \mathrm{O}_{2}$ in photoFenton reactions using metavanadate. Talanta 66, 86-91.

Novo, A., Manaia, C.M., 2010. Factors influencing antibiotic resistance burden in municipal wastewater treatment plants. Applied Microbiology and Biotechnology 87, 1157-1166.

Okeri, H.A., Arhewoh, I.M., 2008. Analytical profile of the fluoroquinolone antibacterials. I. Ofloxacin. African Journal of Biotechnology 7 (6), 670-680.

Oller, I., Malato, S., Sánchez-Pérez, J.A., 2011. Combination of advanced oxidation processes and biological treatments for wastewater decontamination - a review. Science of the Total Environment 409, 4141-4166.

Perez-Estrada, L.A., Malato, S., Gernjak, W., Agüera, A., Thurman, E.M., Ferrer, I., Fernádez-Alba, A.R., 2005. PhotoFenton degradation of diclofenac: identification of main intermediates and degradation pathway. Environmental Science and Technology 39, 8300-8306.

Perez-Moya, M., Graells, M., Buenestado, P., Mansilla, H.D., 2008. A comparative study on the empirical modeling of photoFenton process performance. Applied Catalysis B: Environmental 84, 313-323.

Pignatello, J.J., 1992. Dark and photoassisted $\mathrm{Fe}^{3+}$-catalyzed degradation of chlorophenoxy herbicides by hydrogen peroxide. Environmental Science and Technology 26, 944-951.

Pignatello, J.J., Oliveros, E., MacKay, A., 2006. Advanced oxidation processes for organic contaminant destruction based on the Fenton reaction and related chemistry. Critical Reviews in Environmental Science and Technology $36,1-84$

Radjenovic, J., Sirtori, C., Petrovic, M., Barcelo, D., Malato, S., 2009. Solar photocatalytic degradation of persistent pharmaceuticals at pilot-scale: kinetics and characterization of major intermediate products. Applied Catalysis B: Environmental 89, 255-264.

Rincón, A.G., Pulgarin, C., 2005. Comparative evaluation of $\mathrm{Fe}^{3+}$ and $\mathrm{TiO}_{2}$ photoassisted processes in solar photocatalytic disinfection of water. Applied Catalysis B: Environmental 63, 222-231.

Rizzo, L., Meric, S., Guida, M., Kassinos, D., Belgiorno, V., 2009. Heterogenous photocatalytic degradation kinetics and detoxification of an urban wastewater treatment plant effluent contaminated with pharmaceuticals. Water Research 43, 4070-4078.

Rizzo, L., 2011. Bioassays as a tool for evaluating advanced oxidation processes in water and wastewater treatment. Water Research 45, 4311-4340.

Spuhler, D., Rengifo-Herrera, J.A., Pulgarin, C., 2010. The effect of $\mathrm{Fe}^{2+}, \mathrm{Fe}^{3+}, \mathrm{H}_{2} \mathrm{O}_{2}$ and the photo-Fenton reagent at near neutral $\mathrm{pH}$ on the solar disinfection (SODIS) at low temperatures of water containing Escherichia coli K12. Applied Catalysis B: Environmental 96, 126-141.

Tamimi, M., Qourzal, S., Barka, N., Assabbane, A., Ait-Ichou, Y., 2008. Methomyl degradation in aqueous solutions by Fenton's reagent and the photo-Fenton system. Separation and Purification Technology 61, 103-108.

Watkinson, A.J., Murbyd, E.J., Kolpine, D.W., Costanzof, S.D., 2009. The occurrence of antibiotics in an urban watershed: from wastewater to drinking water. Science of the Total Environment 407, 2711-2723.

Wong, J.W.C., Lia, K., Fanga, M., Sub, D.C., 2001. Toxicity evaluation of sewage sludges in Hong Kong. Environment International 27, 373-380.

Zapata, A., Velegraki, T., Sánchez-Pérez, J.A., Mantzavinos, D., Maldonado, M.I., Malato, S., 2009a. Solar photo-Fenton 
treatment of pesticides in water: effect of iron concentration on degradation and assessment of ecotoxicity and biodegradability. Applied Catalysis B: Environmental 88, 448-454.
Zapata, A., Oller, I., Bizani, E., Sáchez-Pérez, J.A., Maldonado, M.I., Malato, S., 2009b. Evaluation of operational parameters involved in solar photo-Fenton degradation of a commercial pesticide mixture. Catalysis Today 144, 94-99. 